\title{
Research on the Eco-criticism of British Romantic Poetry
}

\author{
Yang Ying \\ English Department \\ Wuhan Insititute of Bioengineering \\ Wuhan, 430415,China
}

\begin{abstract}
Eco-criticism has changed the topography of English Romantic Poetry. The value and significance of classical writers and the works have been criticized in the new readjustment mode. Thus romantic poetry reading and research have generated a lot of new meanings and literature has renewed vitality to be found in the new era of its development. From the perspective of ecological criticism, the British Romantic poet William Wordsworth Classics, Coleridge, Blake, Shelley, Byron and Keats 's works have conducted in-depth interpretation of ecological criticism in romantic poetry, which played the positive role in ecological awareness and ecocriticism Enlightenment thought in the romantic poets of contemporary.
\end{abstract}

Keywords-Eco-criticism, British romanticism, direction of development

\section{INTRODUCTION}

Romantic Movement developed in late 18th century and early 19th century in Europe. It involves the field of literature, philosophy and art. Its main features are advocating individualism and human emotions, respect for nature and so on. Romanticism in the UK mainly in romantic poetry which includes Wordsworth, Coleridge, Byron, Shelley, Keats and other great Romantic poets, and they have created poems to bring people to turn to enjoy immortal poems and spiritual shock.

\section{ROMANTIC POET S' ATTIT UDES TOW ARDS NATURE}

Since the Enlightenment, people are dominated by rational combination of science and technology in the human mind and the human understanding and objective world of fashion has undergone tremendous changes. People regard accumulating technological progress and material wealth as a symbol of social progress, and the attitude towards the nature grows arrogant. Much damage is done to the ecological balance. Due to British industrial revolution and overexploitation caused by the energy crisis, water pollution and air pollution caused by uncontrolled discharge of waste water and waste gas, urban ecological environment deteriorated; social division and machinery make people become slaves of technology and machinery, which severely depressed person's creativity and resulted in distortion of human nature, moral decline and crisis of faith and a series of social problems. Witnessing surging wave of the industrial revolution and technological rationality, the British Ro mantics aware of the gradual decaying of the harmonious relationship between man and nature, as well as the lost civilization and social contradictions, and therefore we must find new meaning and value basis for humanity survival. Divinity of nature is a prominent feature of English Romantic poetry, emphasizing the organic unity of the whole nature. Nature is " some kind of divine presence ", is a intent and spirit "to pro mote the body all thinking and the object of thinking, running between the heavens and the earth "; They emphasize that human and natural ecology of the earth belong to a member of the community of people. We can rebuild a harmonious relationship with nature, return to the true humanity by re- understanding of nature.

In the eyes of the Romantic poets, nature is no longer a simple matter of natural, more non-human conquest and control of objects, but the presence of God and spirituality. It is the source of ideas, strength and noble life, which is able to guide the direction of helping humans restore perfect humanity. For example, in Wordsworth's "Tintern Abbey" (also translated as "Tintern Abbey "), the poet will naturally see themselves as "nanny spiritual mentor, patron saint " and " whole spirit of the true soul." The supernatural realm can give the poet the "Qingming clarity of vision, and an insight into the nature of life." Coleridge expressed in his poetry "God with nature" (divine unity) and "Midnight Frost" that God is natural implication in shaping the invisible things. From the European Renaissance to the Enlightenment, mankind gradually built up a solid self-centered concept. From Romantic poetry, people realize only when people respect the divinity of nature can we live in harmony with nature. Romantic poets think spiritual nature has good impact on human beings. They are more eager to return to nature, to human spirit and to their homes. "Nature" (nature) of both natural and man outside the Western cultural tradition has two inherent meanings. Therefore, romantic poems of returning to nature also contain a double meaning: on the one hand, humans live in harmony with the natural world to return to the embracement of nature; on the other hand, people can remain independent and free, break the shackles of humanity and personality bondage of industrial society to return to the true humanity. 


\section{WORDSWORTH AND NATURAL "RE- ENCHANTMENT"}

As the leader of the Romantic poetry, Wordsworth can be regarded as one of Europe's most prominent eco-writer. Out of disappointment to the French Revolution and the industrial civilization, he lived in the UK for up to fifty years . He lives more in western Lake District to seek the meaning of life. He believes that human nature can be obtained only in the near-god-like sublimation and spirituality. This is life in the spiritual level with attention and involvement, not simply the escaping to the landscape from life. He described the nature sometimes quiet and beautiful, sometimes mysterious. Whether it is a quiet daisies, rivers cuckoo, Pentium singing, or brilliant iridescent, it makes people feel the faith in natural world and belief in harmony. Enjoying the beauty of nature at the same time, Wordsworth pains for Britain's moral decaying. Lack of faith, he see British as a "dead Approach". "Nature or infinitely g lorious sight clas sics no longer makes us interested. Greed, wastefulness, these are idols, we respected. "Poets believe humanity is squeezed in the industrial and commercial civilization and hate society at that time, while nature and the countryside provided a broad space for the stretching of human nature. Fountain pen girl Lucy, the Solitary Reaper and Canterbury old beggar are all living close to nature which show the good nature of human goodness. Wordsworth thinks that people should respect the natural human divinity and consciously return to nature in order to fully appreciate the nature of fraternity and tolerance so that they can realize how ridiculous human thought is. In addition, Wordsworth also believes that children are the closest to their natural state and human nature. In "We are seven", even the little girl's two older siblings have been buried in the grave, she still felt they are with her, so when she insisted repeatedly, the poet said: "We are seven!" $\mathrm{He}$ transcended the understanding of life and death, and broke through the limitations of rational judgment, so the truth has become more user-friendly, which is why there Wordsworth," is the father of the child". The poet hopes adult can get inspiration from children. And their innocence, back to good, honest nature and reverence for nature's heart will not be devoid by modern industrial civilization.

\section{SHELLEY'S "THE BLENDING OF THINGS AND I AND "VEGET ARIAN"}

In addition, the British Romantic poets often use anthropomorphic means to show the natural landscape and power. They described the nature not simply as external nature, but also as the convergence of the poet's inner feelings. I am one member of the nature. As a romantic poet with strong political ideals, Shelley organically blended political criticis $m$ and the pursuit of the ideal society into the vagaries of the depiction of natural scenery. He combines inner spirit to reach the blending of things and I. In his lyrics, "Skylark", the poet sees the skylark as a "mortal mocking those" singing with faith and joy, hating dirty and empty vanity of all earthly tone. In the "Ode to the "west" is a symbol of freedom and power, which went swirling leaves while sown under "flying seed" which has a dual mission of both withering and new birth. Poets devoted an enthusiastic and persistent pursuit of the ideal of freedom to the westerly natural qualities. "I hope you, ferocious spirit, doing my soul! May you this boor, ah, that's me! "Romantic poets combine feelings with the natural landscape. They think human Spirit are higher, and they think human beings are a organic part of nature. Despite its supernatural view, the fundamental research is to promote the harmonious development of man and nature and the rational thinking of its standard of value. According to Shelley's "vegetarian" thinking, people are already familiar with the fact that his paper "for the defense of the natural diet" and "On the vegetarian". He believes that people are born vegetarian animals, "No claws used to capture prey, and no living thing can be used to tear flesh sharp teeth." Natural human diet should be plant and fruit, pasta and fruit, not including the massacre of the bodies of animals. Just because Prometheus steals fire from heaven, human beings can cook food. With the bloody animal meat cooked, people began to accept meat. But Shelley believes that meat is the root cause of human disease and evil, because it violates the natural habits, and disease is the result of unnatural habits. In addition, the meat will increase human cruelty and aggression. Hunting animals will encourage bloodthirsty nature. Over time, humans would degenerate to the point of killing each other, causing wars and bloodshed. It can be said, the meat is at the expense of the life of purity and happiness. Shelley expresses these thoughts in his poems.

In the "Queen Mab" ("Queen Mab"), Shelley described that a pure girl was taken by Queen Mab (fairies) to the space, to see the human beings' past, present and future. Poems showed the history of the past sins of mankind, cruelty and violence, but also demonstrated equality, fraternity, and a bright future. In this bright future, mankind will give up meat habit, reaching harmony with nature. "Then he looked at his face no longer slaughter la mbs / terror that engulfed butchered meat / seems to be revenge for the laws of nature is destroyed, / That meat has stirred all the various corruption body fluids in the human body, and throws in a variety of evil desires / human mind, the false belief that abomination." "All things are no longer a terrorist: People have lost / trample leap privileges, and become equal / equal member in among other members: / although a bit late, after all, joy / and science has begun to appear on Earth." In the" Islamic insurgency, ("Laon and Cythna"), Shelley once again expressed a similar view: "I hope never to have birds of blood / with venom to tarnish the human feast, / Let steaming hot Hanyuan rushed clean -day extension, / should have made venom than that of revenge, / do not let it nurtured disease, fear and madness." Although the source of Shelley's vegetarian ideology is more complex, and it is not thinking of a modern animal rights, but the inside one is full of compassion for animals, for the massacres of evil. As Morton (Timothy Morton) pointed out that Shelley vegetarianism and his political radicalism are closely linked. Animal rights, human rights and women's right receive the same attention. You can say that vegetarianism is Shelley's radical egalitarianis $m$ and fraternity extending in terms of environmental protection and natural diet which has a prototype of ecological thinking. 
Moreover, the ideas of Shaw and Gandhi have a significant impact on the future generation.

\section{CONCLUSION}

Eco-criticism is an interdisciplinary science, which involves biology, geography, physics and other scientific knowledge. At the same time, it involves the history of science, biology and other fields. It is committed to changing the asymmetry between man and nature, unbalanced status and the mentality of human arrogance, and makes the planet truly become a home for all of life, rather than the strong's park, and the hell of the weak. However, in the context of the worsening global ecology, ecological criticism has been very positive in improving the ecological consciousness of contemporary people, changing people's way of life, making it towards a healthier, more rational paradig $m$ shift in the process. Simply throwing ecological criticism out of the window is unwise. In terms of literary studies, ecological critic ism establishes contemporary relevance of romanticism and the environmental crisis, making it a pioneer of contemporary environmental awareness. As a new research paradigm, it has changed the topography of English Romantic Poetry, resulting in the re-evaluation and reshuffling of the romantic poetry. More importantly, ecocriticism makes us see Byron, Shelley and Keats's littleknown ideological orientation and life choices. This makes the romantic poetry reading and research have a lot of new meanings, and makes literature have renewed exuberant vitality.

\section{REFERENCES}

[1] Ni .On Su Manshu and British Romanticism [J]. Xuzhou Normal University (Philosophy and Social Sciences) , 2008, 04:42-47.

[2] Zhao Zenghu. Natural British Romantic poets under the perspective of ecological criticism worship [J]. Henan Normal University (Philosophy and Social Sciences), 2008, 03:200-202.

[3] Fang li. Green's cultural criticism: criticism of the British Ecological Assessment [J] foreign literature, 2013,01:36-44.

[4] Wang Xin . Classic reconstruction sight of British Romantic poetry and women to undergo[J]. Sichuan Normal University (Social Science Edition) , 2013,03:119 - 125 .

[5] [Niu Bingbing. Romanticism banner Shakespeare comments [D]. Shanxi Normal University, 2013.

[6] Duping. Not the same as the East - Byron and Shelley oriental imagination [J] Sichuan International Studies University, 2005, 06:11 $-14$.

[7] Ma Yufeng. Origins and development of Pragmatism [D]. Liaoning University, 2013.

[8] Di Zongjie. Western romance romantic poetry category under [D] Shandong Normal University, 2012.

[9] Xu Jinyu . Against pantheism infinite romantic quest [D]. Zhongshan University, 2011.

[10] Yu Rong. European Romanticism inheritance and development of poetry in the United States [J]. Flowers ,2012,16:161 -162 . 